\title{
REGENERATION OF TREE SPECIES IN AREAS DISTURBED BY TWO HIGH TENSION LINES AT SEETHA ELIYA PROPOSED FOREST RESERVE
}

\author{
D) K Angammana', (; I Seneviratne ${ }^{1}$ and K Nanayakkara ${ }^{2}$ \\ 1Department of Botany, University of Colombo \\ ¿Botanical Garden, Hakgala
}

Seven years ago, to erect a high tension line a strip of forest (10 $1015 \mathrm{~m}$ broad) from the Sectha Eliya reserve was cut leaving stumps of about one meter height. This was abandoned and a similar strip close to the above has been cut three years ago. This project was carried out to find the plant species which can survive after such disturbance and to see the change in the tree species composition with time. Sectha Eliya is a montane forest patch with undulating terrain and the altitude of the affected area ranges from 5000 to 6000 feet. After a recomnaissance survey, 36 plots of $8 \times 25$ has been demarcated at three altitudinal ranges (low, mid and high) to include three year, seven year and the adjacent natural forest (four at each site).

The percentage of trees surviving after culling in the three year old stand from high, mid and low altitudes were $4.3 \%, 51 \%$ and $52 \%$ respectively. Survival after cutting in the sevenyear-old stand is not obtainable accurately due to the decomposition of stumps.

A tolal of 37 tree species including 26 endemic species were recorded in the areas examined. Out of this only 27 species including 16 endemic species showed the ability to produce new shoots. Higher number of such individuals were recorded from, Neolitsea fuscala, Syzygium revolutum. Actinodaphne glanuca and Cinnamomum ovalifolium. Species like Calophyllum walkeri, Vaccinium symplocifolium, Chthium montamum did not show regencration alter cutting. Artinodaphe speriosa was found both in the natural forest and the lihee-year-old stand but was absent in the seven-ycar-old clearing, probably removed due to competition.

Higher number of secdlings and saplings were found from Symplocus cochinchinensis, Neolitsea fuscata and Actinodaphene speciosa in all the areas examined.

Further monitoring of these areas will help to identify the native species those can be used in restoration work of montane forests. 